\title{
Burrowing pattern and damage caused by the rodent pest, Indian house rat (Rattus rattus) in the Gangetic and Non Gangetic plain of West Bengal, India.
}

\author{
Debiprasad Chattopadhyay ${ }^{1}$, Nithar Ranjan Madhu ${ }^{2}$ and Chanchal Kumar Manna ${ }^{1}$ \\ ${ }^{1}$ Endocrinology Laboratory, Department of Zoology, University of Kalyani, Kalyani 741235, W. B., India \\ ${ }^{2}$ Bajkul Milani Mahavidyalaya, Kismat Bajkul, Purba Medini Pur, West Bengal-743287.
}

Keywords: Burrowing pattern, hoarding materials, Gangetic and non Gangetic plain, laterite, alluvial.

Rodents, one of the important vertebrate pests (Advani \& Mathur, 1982) are directly related to the production and storage of crops and their utilization by man and livestock. It has been identified as the most important mammalian agricultural pests at the global level (Cuong et al., 2002). The effect of rodent damage causes huge amount of crop losses and food shortages (Fayenuwo et al., 2007; Amusa et al., 2005) in some parts of the world. A large amount of crops during pre and post harvesting periods are being lost every year (Meerburg \& Kijlstra, 2008). Among rodent pests, wild Indian house rat (Rattus rattus) is seriously active and a threat to the agricultural advancement in West Bengal, India. The Gangetic and non Gangetic plain of West Bengal are characteristically different to their soil structure and composition. The Gangetic plain is dominated with sandy alluvial soil, while the non Gangetic plain and especially the rarh region of West Bengal are dominated with hard laterite soil. Rainfall, temperature, humidity and crop pattern are also different in these regions. During pre harvesting and post harvesting periods the rodents destroy tillers of crops and store them within the hoarding chambers of the burrow. Observed $4.6-5.4 \%$ of rice and $11.9 \%$ of wheat is lost due to rodent damage in India (Srivastava, 1970). The house mouse (Mus musculus) is also found in large numbers in residential buildings, stored godowns, and poultry farms as well as in the fields (Barnett \& Prakash, 1975). They also cause damage in the stored godowns and cultivated fields. Generally rats burrow for nesting and harbourage. Freshly dug dirt is scattered in front of 3 inches opening with runway. It is about 18 inches deep in moist soil. In burrow system of rat entrance, tunnel, cavity, nesting and hoarding chambers are clearly demarcated. Solitary fossorial mammal do constructs significantly large nest chamber.

In the present study, we estimated the actual rodent damage and yield loss in rice field and wheat field in two separate environments i.e., Gangetic and non Gangetic plain of West Bengal,
India. Depending on the soil structure, the pattern of burrows should be different. The present research aims to provide a sound basis for future work to understand the damage and yield loss estimation, burrow pattern and various pest management evaluations.

Study area: Studies were conducted at the Gangetic (Districts of Nadia and North 24parganas $\mathrm{N}$ ) and non Gangetic (Bankura and Purulia) plains of West Bengal, India. About six unit fields (one acre) were selected from each district. Data and photographs were taken for quantitative and qualitative analysis. Burrows were counted throughout (central and periphery) the field in both the cropping seasons. Standard excavating instruments were used to dugout the burrows. Hoarding materials were collected, weighed and kept properly for further analysis.

Statistical analysis: All the observations in relation to assessment of damages and relevant items i.e., the diameter of burrow opening, length of burrow, depth of burrow, hoarding materials within the burrow in relation to burrow pattern, were studied and the data were recorded, analyzed statistically with student's t-test and Pearson correlations procedures using SPSS 10.0, USA.

\section{Damage assessment model}

A simple bioenergetics model (cited by Sultana \& Jaeger, 1992) was used to estimate each site and cropping season. Damage was the product of the number of rat days in a crop and the amount that a rat damages per day. The number of days per acre per crop per month was calculated as a function of a linear change in average density of burrows of 60-90 days sampling interval. Here initial burrow number was mentioned as $A$ and final burrow number was $C$. The equation which we followed was:

$$
\begin{aligned}
T_{R} & =\int_{0}^{30}\left[A+\frac{(C-A)}{30} x\right] d x \\
T_{R} & =\text { Total rat days }
\end{aligned}
$$


$A=$ Initial burrow number

$\mathrm{C}=$ Final burrow number

For example, if the average number of burrows per acre of wheat increased form 5 to 25 , then

$T_{R}=15(A+C)=15(5+25)=450$

TR is converted to damage by multiplying by $75 \mathrm{~g}$, a constant which represented what we determined as the average daily damage of an adult $R$ rattus (consumption plus hoarding).

Burrow pattern: Ten burrows were excavated from each unit field of each district. In both the regions minimum number of opening was 4 and maximum number was 6 per burrow. The mean diameter of burrow opening of $R$. rattus was about $7.62 \pm 3.32 \mathrm{~cm}$. The depth of burrow in the non Gangetic plain was $27.305 \pm 9.884 \mathrm{~cm}$ while in Gangetic plain it was about $40.321 \pm 5.396 \mathrm{~cm}$. The average length of the burrow to its long axis in the gangetic plain was $420.00 \pm 67.66 \mathrm{~cm}$, and $145.84 \pm 106.19 \mathrm{~cm}$ in the Non Gangetic plain. All these results were properly recorded and presented in the table (Table 1, 2).

Simple type of burrow was observed in Purulia and Bankura districts (laterite soil) in comparison to Nadia and north 24-paraganas districts (alluvial soil) but in wheat season it was more complicated than rice season in both the plains. The number of burrow was increased at the centre of the field during the time of ripening of crops. Through excavation procedure, different chambers like resting, nesting and hoarding were observed (Fig 1). Nesting chambers were always found situated far from the opening which was mainly the blind tunnel. Crops were found stored not only within the hoarding chambers but also at the side wall of the tunnel in some places. Temperature inside the burrow was lowered by $5-6^{\circ} \mathrm{C}$ than outside in both the regions (Table1).

Fig 1. Graphical representation of various chambers of burrow pattern of Rattus rattus

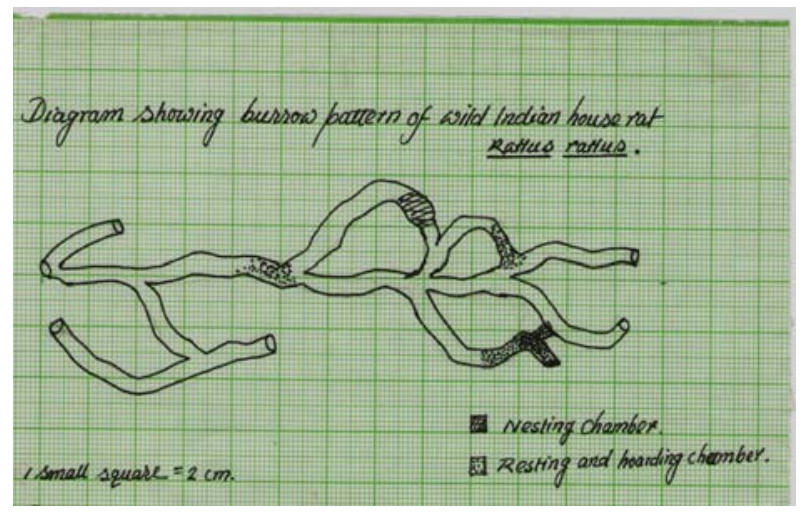

Hoarding materials: 1.06 to $2.18 \mathrm{~kg}$ of wheat with panicle and $0.95-1.02 \mathrm{~kg}$ of rice with panicle were stored within the burrow in all the regions (Table 1). Hoarding materials within the burrow were often found to relate to crops surrounding the burrow.

Table 1. Showing data regarding burrow pattern of Rattus rattus in four districts of the Gangetic and non Gangetic plain of West Bengal.

\begin{tabular}{|l|l|l|l|l|}
\hline & Gangetic & \multicolumn{3}{|l|}{ Non Gangetic } \\
\hline & NADIA & 24 PGS(N) & Bankura & Purulia \\
\hline No of & 5.60 & 6.00 & 4.10 & 2.30 \\
Opening* & $\pm 1.074 * *$ & \pm 0.774 & \pm 0.737 & \pm 0.483 \\
\hline Diameter of & 7.62 & 7.62 & 7.62 & 7.62 \\
opening(cm) & \pm 3.321 & \pm 3.321 & \pm 3.321 & \pm 3.321 \\
\hline Depth of & 37.84 & 42.79 & 34.03 & 20.574 \\
Burrow (cm) & \pm 4.706 & \pm 5.072 & \pm 7.103 & \pm 7.424 \\
\hline length of & 405.00 & 435.00 & 246.00 & 45.694 \\
Burrow (cm) & \pm 59.860 & \pm 74.721 & \pm 35.023 & \pm 16.993 \\
\hline Hoarded rice & 1.50 & 1.02 & 0.95 & 1.005 \\
(kg)/burrow & \pm 0.577 & \pm 0.674 & \pm 0.437 & \pm 0.705 \\
\hline Hoarded wheat & 2.10 & 2.18 & 1.06 & 1.37 \\
(kg)/burrow & \pm 0.614 & \pm 0.616 & \pm 0.480 & \pm 0.637 \\
\hline
\end{tabular}

*Number of burrows: 10 from each district.

** Mean \pm Standard deviation.

Litter size: Mean litter size varied with the regions and with the crops. 5-6 litters were found in both the regions. In wheat field it was larger than the rice field.

\section{Damage assessment}

Rat days in rice and wheat season from the Gangetic and non Gangetic plains were calculated. Rat days for rice season were larger than that of wheat season. It was calculated that $6-8 \%$ of rice and $10-12 \%$ of wheat was lost every year in both the Gangetic and non Gangetic plain of West Bengal.

Table 2. Showing $\mathrm{t}$-value and $\mathrm{r}$ - value of data regarding burrow pattern of Rattus rattus in four districts of the Gangetic and non Gangetic Plain of West Bengal.

\begin{tabular}{|l|c|c|c|c|c|c|}
\hline & $\begin{array}{c}\text { Number } \\
\text { of } \\
\text { Opening }\end{array}$ & $\begin{array}{c}\text { Diameter } \\
\text { of } \\
\text { Opening } \\
(\mathrm{cm})\end{array}$ & $\begin{array}{c}\text { Depth of } \\
\text { Burrow } \\
(\mathrm{cm})\end{array}$ & $\begin{array}{c}\text { Length of } \\
\text { Burrow } \\
(\mathrm{cm})\end{array}$ & $\begin{array}{c}\text { Hoarded } \\
\text { Rice }(\mathrm{kg})\end{array}$ & $\begin{array}{c}\text { Hoarded } \\
\text { Wheat } \\
(\mathrm{kg})\end{array}$ \\
\hline $\begin{array}{l}\text { Gangetic } * * \\
\text { Plain }\end{array}$ & $5.75^{\star}$ & 7.62 & 40.321 & 420 & 1.26 & 2.14 \\
\pm 0.828 & \pm 3.321 & \pm 5.396 & \pm 67.667 & \pm 0.658 & \pm 0.600 \\
\hline NonGangetic & 3.2 & 7.62 & 27.305 & 145.847 & 0.977 & 1.22 \\
Plain $* *$ & \pm 1.105 & \pm 3.321 & \pm 9.884 & \pm 106.190 & \pm 0.572 & \pm 0.572 \\
\hline r value & $0.05231 \#$ & 0 & 0.0373 & 0.2154 & -0.3362 & -0.0852 \\
\hline $\mathrm{t}$-Test & $8.1775^{\star \star *}$ & 0 & $5.251^{\star \star *}$ & $10.854^{\star \star *}$ & $1.2541^{\star \star *}$ & $4.763^{\star \star *}$ \\
\hline
\end{tabular}

* Mean \pm Standard deviation, ${ }^{* \star}$ Number of burrows: 20 from each plain, *** Significant at $p<0.05$, \#Pearson Correlation value. 
A huge amount of crop is being lost every year in India due to rodent pest. Rodents cause damages to young plants, fruits, seeds, panicles of the paddy and wheat both in the field and houses. From the present study it is observed that the damages of plants by the rodent pest were reported to be maximum in the District Nadia. Amongst the various rodent pests, percentage of $R$. rattus is quite preponderant in two plains. In Philippines also, $R$. rattus continued to eat rice as late as eight months after the harvest (Tigner \& Wallace, 1972).

In the Gangetic and non Gangetic plain, it has been estimated that the total amount of damages exceeded $6-8 \%$ of rice and $10-12 \%$ of wheat. Annual food losses caused by rodent in India are estimated to be $10-15 \%$ of the total national production (Barnett \& Prakash, 1975). Usually $R$. rattus breeds throughout the year where as peak was in the months of July-April and JanuaryMarch. Litter size was 2-8 per nest. It has been reported that in the districts Hooghly and Nadia, it may vary from 6 to 8 , in north 24-parganas 4 to 6 . Number of burrows was counted thoroughly in both the cropping seasons of the fields of Gangetic and non Gangetic plains. These results indicated that the number of burrows in the centre of the mature wheat field were higher than the periphery. Santra \& Manna (2008) also studied the damage assessment in four districts in the Gangetic plain of West Bengal. The report of that the number of burrow is directly correlated with the crop loss. The diameter of burrow opening indicates the presence of infested rodent species (Prakash \& Ghosh, 1992). The diameter of entirely studied burrow opening varies from 3.18$9.65 \mathrm{~cm}$, in Mus sp. $3.18-3.80 \mathrm{~cm}$, in Rattus sp $7.62 \mathrm{~cm}$ and $8.9-9.65 \mathrm{~cm}$ in Bandicoota sp.Tunnels of $G$. capensis had a mean diameter of $8.7 \mathrm{~cm}$. In Purulia district burrow tunnels were mainly unbranched and present at the centre of the rice field.

Average length of the unbranched tunnels was about $40-45 \mathrm{~cm}$. In marshy areas Bandicoot produce some simple burrows such burrow consists of unbranched tunnels up to $72 \mathrm{~cm}$ in length and $6-14 \mathrm{~cm}$ in diameter. These burrows are mainly utilized feeding places after the capture of the prey. The present observation indicates different chambers like resting, nesting, hoarding within the burrow. It was also observed that the nest chamber was situated far from the nearest opening. So it remains undisturbed to the litters. Crops, surrounding the burrow, were stored not only within the hoarding chambers but also at the side wall of the burrow and each burrow consist of one or more openings on the surface (Chakraboty, 1982). The complexity of burrow pattern was directly related to the period of occupation. Complicacy regarding burrow pattern in the Gangetic plain may be due to soft alluvial soil while it was simpler in hard stony (laterite) soil of the Bankura and Purulia districts of the non Gangetic plain. This burrow pattern varies with the structure of soil and with types of crops. This study clearly indicates that Rattus $s p$ is quite preponderant in the cultivated fields of both the Gangetic and non Gangetic plain of West Bengal. The diversity of burrow pattern of this species depends on the type of soil and nature of crops which is evident from this study.

\section{Acknowledgements}

The authors are indebted to the farmers of the districts Nadia, N-24 Parganas, Bankura and Purulia, West Bengal, India, for providing valuable data and immense help during the time of this study. Partial financial assistance from the UGC minor research project, F-PSW-066/08-09(ERO), awarded to Dr.N.R.Madhu, is also heartily acknowledged.

\section{References}

Advani, C.R. \& Mathur, R.P. 1982. Experimental reduction of rodent damage to vegetable crops in Indian villages. Agro ecosyst. 8: 39-45.

Amusa, N.A., Iken, J.E. \& Fyenuwo, J.O. 2005. The incidences of Field diseases and Vertebrate pest on popcorn (Zea mays everta) Varieties cultivated in agro forest ecologies in Nigeria. World J. of Agric. Sci., 1(2): 173-177.

Barnett, S.A. \& Prakash, I. 1975. Rodents of economic importance in India. Arnold Heinemann Publ. New Delhi: 175-185.

Chakraborty, R. \& Chakraborty, S. 1982. Food habits of larger bandicoot rat, Bandicota indica (Bechstein) in the fields of west Bengal during rainy season. Rodent Newsl., 6: 27-30. 
Cuong, L.Q., Chien, H.U., Han, L.U., Duc, V.H. \& Singleton, G.R. 2002. Relationship between rodent damage and yield loss in rice in MekongDelta. In: Rats, mice and people; Rodent Biology and Management (Grant R, Singleton, Lyn A. Hinds, Charles J. Kebs and Dave M.Spratt. eds.) Australian Center for International Agricultural Research. Canberra: pp. 217-219.

Fayenuwo, J.O., Olakojo, S.A., Akande, M., Amusa, N.A. \& Olujimi, O.A. 2007. Comparative Evaluation of vertebrate pest damage on some newly developed quality protein maize (QPM) varieties in south western Nigeria.Afri. J. Agri. Res., 2 (11): 592-595

Meerburg, G. \& W.A. Kijlstra. 2008. The ethics of rodent control. Pest Management Science., 64(12): 12051211.

Prakash, I. \& Ghosh, P.K. 1992. Rodents in Indian Agriculture, Vol. 1, Scientific Publishers, Jodhpur, India.
Santra, K.B. \& Manna, C.K. 2008. Studies of some aspects of rodent ecology in the four districts of the Gangetic plain of West Bengal, India. Univ.J. Zool.Rajshahi Univ., 27: 85-90.

Srivastava, A.S. 1970. Project Coordinators Final Report on the all India Coordinated scheme for Research on the study of field Rats (1959-69). New Delhi, ICAR: 1-147.

Sultana, P. \& Jaeger, M.M. 1992. Control strategies to reduce preharvest rat damage in Bangladesh. Proc. 15th Vertebrate Pest Conf. (J.E. Borrecco \& R.E. Marsh, eds.) University of Calif., Davis. pp 261-167

Tigner, J.C. \& Wallace, R.J. 1972. Hoarding of food and non food items in blind anosmic and intact albino rats. Physiology and Behavior 8(5): 943-948. 